\title{
CURRENT SITUATION OF CIVIL AWARENESS OF UNDERGRADUATE AND PROMOTION STRATEGY RESEARCH
}

\begin{tabular}{l} 
MA Li Hong-Mei, School \\
Dr. Li Guo-Jun, School \\
MA Shi Hong-Fei, School \\
Dr. Feng Zi-Ming, School of Mech \\
\hline A R T I C L E I N F O \\
Original Research \\
Received: December, 12.2016 \\
Revised: February, 26.2017. \\
Accepted: March, 17.2017. \\
doi:10.5937/IJCRSEE1701001H \\
UDK \\
37.035.6-057.875 \\
172.12/.15-057.875 \\
\hline
\end{tabular}

Keywords:

college student, citizen consciousness, education situation, promotion strategy.

\begin{abstract}
A B S T R A C T
We conducted on a questionnaire survey for the current college students' civic awareness from four aspects of equality consciousness, national consciousness, freedom consciousness and public consciousness. Survey data was analyzed with the SAS ${ }^{\circledast}$ statistical software, the results shown that some of our country's College Students with a strong national consciousness, and their patriotic feeling is deep at present. They identity the consciousness of equality, but their awareness of fighting for rights is not strong. They have a sense of freedom, but some students are not clear about the relationship between freedom and law. Their enthusiasm to participate in public affairs is not high. Their awareness of social morality is not comprehensive. The reason is that the influence of traditional culture and the political development can't keep up with the development of economy and the systematic citizenship education is lacked. Finally, we put forward a method of improve the civic awareness of Contemporary College Students in this paper.
\end{abstract}

(C) 2017 IJCRSEE. All rights reserved.

\section{INTRODUCTION}

In 1978, the comrade Deng Xiaoping put forward the reform and opening-up policy. The reform and opening-up policy is the key choice to decide the fate of China in the future. It is the only way to develop the socialism with Chinese characteristics and to realize the great rejuvenation of the Chinese nation. With 30 years of economic development, GDP in 1978 was 2,168 hundred million dollars, in 1993 broke $\$ 5,000$ hundred million dollars, and in 1998 broke $\$ 10,000$ hundred million dollars. In 2009, China's GDP broke 50,000 hundred million dollars with $\$ 50,597$ hundred million dollars. In 2010, it surpassed

Corresponding Author

MA Li Hong-Mei, School of Marxism, Northeast Petroleum University, Daqing, China

E-mail: xueyuanlhm@163.com

This work is licensed under a Creative Commons Attribution - NonCommercial - NoDerivs 4.0. The article is published with Open Access at www.ijcrsee.com
Japan and became the second economic entity in the world. In 2014, it broke 10 trillion with \$103,611 hundred million dollars (China GDP Report. 2015). China's investment in education was also growing. In 1995, the number of teachers in China was 3,334,200. In 2013, the number of teachers in China was 5,099,000 people. In 2008, there were 2,263 colleges and universities in China and the number reached 2,529 in 2014 . In 2008, the direct public expenditure of public educational institutions in China was accounted for $3.3 \%$ of GDP and it reached 4\% in 2012 (National Data Report. 2015). Compared with the speed of economic development, the investment of education was still low, but the overall trend was better than before. It indicated that China economy and education had gained the rapid development over the past 30 years and achieved fruitful results. But the development of civic awareness was fell behind the economy development. To improve the citizen consciousness of the College students, it was necessary to make a thorough research on the domestic citizen's consciousness of present situation and built up 
a method to improve college students' citizen consciousness.

With the rapid development of our country socialist market economy, the construction of democracy, the rule of law, the development of modern civilization and the College Students' civic awareness education all had achieved a considerable development. The College students are the backbone of building a modernized country. To strengthen civic awareness education of college students, it need cultivate qualified citizens to meet the development of the socialist market economy and need build a socialist country with law. And it is also an important task for the Ideological and Political Education in Colleges and universities (Xie, 2009). Firstly, this paper explained the basic concepts of civic consciousness; secondly, it analyzed the current situation of College Students' civic consciousness; lastly, it putted forward the methods and strategies to improve the civic awareness of contemporary college students. This paper provided the necessary theory basic and method for cultivating the students to be the qualified citizens with loving their motherland, loving socialism, having correct concept of right and obligation, having spirit of innovative and subject consciousness.

\section{MATERIALS AND METHOD}

\subsection{Citizenship and its connotations}

The concept of "citizenship" was formed early in ancient Greece and Rome, and the city had already appeared civic role (Marx, Engels, 1957). At that time, the concept of citizenship was essentially unequal social classes (Marx, Engels, 1995). In Roman times, only a small number of people could become citizens, citizenship was not general enough. Middle Ages was impossible to develop a good civic awareness. 17th and 18th century, the Enlightenment made people to be aware more deeply of the "democracy, freedom and equality" than before (Mao, 1991).

Since 1970s, the concept of civil society has been mentioned again and has just started to be used by some western people to criticize the real society and to introduce the ideal society. In period of the late 1980 s to the early 1990s, because Eastern Europe and Soviet Union had happened huge changes, the study of Western civil society formed an unprecedented boom. After the 1990s, the theory of civil society began to spread from the West and the Soviet Union to other countries and regions in the world and was used to explore the construction of its own civil society.

Citizen consciousness is the self-recognition of individual citizens in the country. The basic rights and duties is the base for citizens. The constitution and the law are the core content for citizen consciousness, which reflect their dominant position in political and social life and merge the country's sense of responsibility, the sense of mission and the view of the rights and obligations of self-awareness. It revolves around the relationship between the rights and obligations of citizens to reflect citizens' treat moral concepts, values, norms of behavior between the individual and the state, between the individual and society, between the individual and others. It emphasized that the sense of responsibility of people in social life, civic awareness, sense of democracy and other basic moral sense (Jiang, 2010).

Thus, the modern civic consciousness is the consciousness of the citizen's political sovereignty and is the sovereign consciousness to participate in the management of state affairs. It includes two levels of meaning; the right to participate in the management of state affairs and the sense of responsibility to maintain the good functioning of society. Specifically, these two levels of consciousness can be internalized as equality, freedom, national and public awareness.

1) Equality Awareness: Sense of equality is the core meaning of citizenship. Hellenistic polis citizens have limitations qualifications on an equal sense of identity. Necessary and sufficient conditions of the citizens of Athens Times is: if he has the right to participate in the proceedings and judicial functions of people, he is a citizen of that city (Wu, 1965). Since the bourgeois revolution in modern, citizen theory is more egalitarian than before and emphasize the equal rights of citizens in public affairs in the participating countries. Our Constitution also stipulates that citizens of People's Republic of China are equal before the law and every citizen enjoy the rights of Constitution and the law and must fulfill obligations under the Constitution and the law.

2) Free Consciousness: In general, freedom is acted on our own without any restrictions and constraints. Freedom consciousness is the awareness and understanding of the rights of citizens that is given by the law and is not restricted or limited.

3) National Consciousness: Citizens come from the city-state's rule, which intent has the regional restrictions. this concept has 
subsequently changed, but in the modern national political system, the state is still a prerequisite for the survival and development of the citizens. Therefore, the national consciousness is the most basic consciousness of the citizen consciousness.

4) Public Awareness: In modern realm of politics, the citizens are the unity of rights and obligations. The society is made up of many citizens who must observe the public contract under the law. Only in this way, we can ensure the social develop orderly and sanely, which includes the awareness of participation in public affairs and the observation of social compliance.

\subsection{Present situation of contemporary college students' civic awareness education}

In this paper, the samples of college students' civic awareness survey are the Engineering College Students by questionnaire. From Sep 2015 to Nov 2015 in Heilongjiang Province, we issued 270 questionnaires in 3 colleges to investigate the current situation of College Students' civic consciousness. The questionnaire includes the citizen's equality consciousness, freedom consciousness, national consciousness and public consciousness, which let the students answer the question in details. In this investigation, the whole group sampling method was used to select the random sample in different undergraduate courses. The science students were issued 90 copies; the arts students were issued 90 copies; the engineering students were issued 90 copies, which the total numbers were 258 valid questionnaires with $95.6 \%$ effective recovery rate. The research results were analyzed by $\mathrm{SAS}^{\circledR}$ v. 9.2, which was a statistical analysis software, and then a discussion was conducted by using the analysis results.

\section{RESULTS}

The statistical analysis of the questionnaire shown that the students of our country's civic consciousness were in the following aspects:

1) The national consciousness is strong, and the patriotic feeling is deep

The survey shown that $96.9 \%$ of college students had a strong national consciousness with high national responsibility and patriotism. For example, the "Chinese Threat The- ory", "Xinjiang Independence" and "DiaoYu Islands" and other issues were expressed strongly concerns by students. We are proud of the achievements of our country's economic construction, but at the same time, we can see that the comprehensiveness of the basic values of the socialist system of our country and the traditional culture is less, which only $52.3 \%$ of the students have a firm belief.

2) They approve the equality consciousness, but have no consciousness to fight for their rights strongly

Survey shown that 77.5 percent of college students praised Martin Luther King and Nelson Mandela who are seeking the equal rights of black, which indicated that contemporary college students had widely approved the sense of equality. But 91.1 percent of college students surveyed in the face of unequal treatment will be endure, which indicated that college students have a greater inequality for tolerance because of the impact of traditional culture, and chose not to fight.

3) They have a sense of freedom, but few students know the relationship between freedom and law

Ninety eight point one percentage of the students for the pursuit of the spirit of freedom had a positive attitude identity and their understanding of the sense of freedom were correct. But pursuing the freedom of consciousness is not ideal. Most students can't treat well their own matter, and only a few students have a strong self-reliance.

4) Their enthusiasm for participation in public affairs were not high, and didn't comprehensive understanding of civic awareness

Public awareness can be divided into two sides: conscious participation in public affairs and civic awareness levels. Only $30.2 \%$ of the students were active in public affairs for the class, and $25.2 \%$ of students often concerned about national affairs, which reflects that the contemporary college student's enthusiastic participation in public affairs is not high. As to civic awareness, college students have a strong civic awareness in some respects. There were $80.2 \%$ of college students giving the old seats, and $95 \%$ of college students showing the stranger the way. However, nearly $60 \%$ of the students had run the red light. It is shown that the contemporary college students didn't fully cognitive the civic awareness and often handled matters by their feeling. 


\section{DISCUSSION}

\subsection{Reason Analysis}

\section{1) Traditional cultural influences}

The so-called culture is that people gather together in the long life of social life (Sha, 1965). Our long history and cultural heritage of thousands of years of Chinese civilization produced many excellent traditional culture in the current world, which has a very positive meaning, such as the patriotic ideas that everyone is responsible for the rise and fall of our state, kindheartedness that is the basis of confucian morality and consciousness. These ideals are all coincided the contemporary connotation of the citizen consciousness. However, in traditional Chinese culture, the official oriented consciousness was very entrenched privilege since ancient times. The prerogative was act as a large and rigorous system and deeply rooted in the political, economic, cultural and social. The pursuing of equality and liberty was influenced by the imperial power or authority, and didn't get rid of dependence on people. This conflicted with the modern civic consciousness.

\section{2) Social development in transition}

Currently, our society is still in the political system that is not fully adapted to the stage of market economy. The lack of restraint system and the value system, the personal interests for economy, rampant materialism, the traditional moral bottom line was collapsed. The negative impact of social environment leaded the values of some college students accepting the negative tendency, weak sense of collective, serious money worship and hedonism. They only willing to enjoy the rights and willing to assume their responsibilities, but their civic awareness was weak. tion

3) Lack of systematic citizen educa-

The practice indicated that the formation of citizen's consciousness didn't separate from the acquired education. In recent world, the developed countries paid attention to the construction of citizen education system. Since reform and opening-up, China has gradually increased the degree of the attention to the citizen education. However, due to the lack of a sustainable education concept, excessive politicization, and one-sided emphasis on sermons it was resulted in that the citizen consciousness education of school didn't make students generate personality of independent, self-discipline, in contrast, produced the per- sonality of the blind obedience that is incompatible with the civil society of contemporary democracy and rule by law (Gu, 2008).

\subsection{Improving college students' awareness of citizen's consciousness}

1) Strengthen the ideological and political education and improve the political participation quality and ability of college students

The current ideological and political education in college paid more attention to theory and less to practice, and the educational form is relatively single, which was uncoordinated between educators and education object. Therefore, the reform of the ideological and political education should be put on the agenda, and the traditional "spoon feeding' way of teaching method should be replaced. Raising the dominant position of young students in the course, which can stimulate their enthusiasm for politics, improve their political participation consciousness and behavior. The citizen consciousness education should guide students to establish a "political socialization" idea to cultivate obligations of concerning about the country, the society and the world, and should let students think that the politics are surely closed to themselves, and learning politics is useful for them. Thus, the students' political enthusiasm will be aroused.

2) Create a good atmosphere for college students' civil education

Due to historical reason, our country's democratic and citizen consciousness education degree was very low. The whole society cultural atmosphere was lack of the spirit of equality, freedom, faith and so on. Therefore, to get good effect of citizen education, our government, society and school must cooperate by whole hearts. Firstly, because the life and learning of college students are mainly in the campus, the campus environment will directly affect the cultivation and development of citizen consciousness of college students. Therefore, colleges and universities should make great efforts to establish the campus culture with full of freedom and equality thoughts, and encouraged and advocated the students' independent thinking to form a good cultivation environment of citizen consciousness.

Government departments must have a long-term education planning guidance and policy, and should also speed up the pace of the construction of the rule of law. The rule 
of law is the appearance of the democratic spirit. The social environment of our country now should be optimized to make a complete legal system which is in accordance with the time values and to strengthen the publicity and education of all people who are same in front of the law, and to increase public opinion guidance to achieve promoting righteousness and exposing ugly to optimize the social environment of public opinion and establish good value orientation.

3) Participate in school management and increase the chance of college students' political participation

Participating in school by college students is one of the important characteristics of modern university system. It is also an important opportunity for college students to participate in students' politics, is the best interpretation of college students' citizen education. It has an important significance to promote the institutionalization, scientific and democratization of colleges and universities management. There are many various ways to participate in school management:

1. Participate in the formulation of university rules and regulations

Participating in the formulation of universities is a typical participatory governance for college students. University regulations are formulated as legislative activities, which should also be made in accordance with the requirements of due process. College students are the largest group in the university, so they should enjoy the right of management of the school and their own affairs. Participating in college management is the legal requirements.

2. Participate in the evaluation of teaching activities

With the method of students evaluating management departments, colleges and the interests of teachers' directly, students who are managers really have the identity and rights of management. Only the interests and needs of students have been paid attention and protected, the talent cultivation will be become as a central task for the college.

3. Participate in social work and widen the channels of political participation of college students

College students can go into the community, school and enterprise to participate in colorful social work as a volunteer. They can use group and intellectual advantages to carry out social surveys, understand the public opinion of people, and provide information on government. They can cooperate with social organizations to carry out public welfare ac- tivities, undertake the government public service projects and provide an assistance for the vulnerable groups in society. All in all, there are many various social practices waiting for college students to explore and develop continuously with subjective initiative.

\section{CONCLUSION}

With the rapid development of Chinese political and economy and the continuous changing of social structure, the contemporary college students' citizen consciousness need a higher requirement than before. In this paper, the current college students' citizen consciousness has carried on with the questionnaire survey. Analysis results shown that most of the current college students have strong national consciousness and patriotism and are strongly desiring for freedom and equality. College students have low enthusiasm on participation in public affairs and less comprehensive of public awareness. Therefore, we should insist on the educational thought of setting up and cultivating person's morality, should earnestly carry out educational work, and should make effort to cultivate the Chinese characteristics of the socialist builders.

\section{ACKNOWLEDGMENTS}

The authors gratefully acknowledge the follow Project Funded by China Heilongjiang Province Education Scientific Planning Project No: GJB1214007. Teaching Reform Project of Northeast Petroleum University No: JGXM NEPU_201607. Heilongjiang Province Postgraduate Pedagogy Innovation Engineering Funded Projects, No. JGXM_HLJ_2016043,

\section{Conflict of interests}

Authors declare no conflict of interest.

\section{REFERENCES}

China GDP Report. (2015). Retrieved June 30, 2015, http://baike.haosou.com/doc/3919754.html

Gu, C. G. (2008). Civil Society and Citizen Education. Beijing: Intellectual Property Press.

Jiang, G. H. (2010). Constitution and Citizenship Education. Wuhan: Wuhan University Press.

Mao, Z. D. (1991). Mao Zedong Selection. Vol.1, Beijing: People's Publishing Press.

Marx, K. H., Engels, F. V. (1957). Marx and Engels Corpora. Vol.1, Beijing: People's Publishing Press.

Marx, K. H., Engels, F. V. (1995). Marx and Engels Corpora. Vol.4, Beijing: People's Publishing 
(IJCRSEE) International Journal of Cognitive Research in Science, Engineering and Education Vol. 5, No.1, 2017.

Press.

National Data Report. National Bureau of Statistic of China. (2015). Retrieved June 30, 2015, http:// www.stats.gov.cn/tjsj/ndsj/2015/indexeh.htm

Sha, L. X. (1965). Traditional Culture and Modernization. Beijing: Ren-Min University of China Press.

Wu, P. S. (1965). Politics Science. Beijing: Commercial Press.

Xie, G. A. (2009). Present Situation of Our Country Undergraduate' Citizen Consciousness and Education Solution Analysis. Journal of Socialist Theory Guide, 10, 53-54. doi: 10.3969/j. issn.1002-7408.2009.10.018 